半導体材料プロセスにおける原子層成長の展開 : 薄膜作製装置のクリーニング技術*

羽深等*1

\title{
Advance of Atomic Layer Deposition in Semiconductor Materials Manufacturing Process: Cleaning Technology for Thin Film Formation Reactor
}

Hitoshi HABUKA*1

*1Department of Chemical and Energy Engineering, Yokohama National University, 79-5 Tokiwadai Hodogaya-ku Kanagawa 240-8501, Japan

(Received July 7, 2010, Accepted August 24, 2010)

Reactor cleaning processes have been discussed and designed for atomic layer deposition of hafnium oxide film, taking into account the information of silicon epitaxial growth process. One of the key points for designing the reactor cleaning technique is the production of chemical compounds which can be vaporized at low temperatures. Chemical reaction between hafnium oxide and hydrogen chloride was studied and showed that the hafnium chloride was effectively produced by hydrogen chloride gas at temperatures higher than 300 ${ }^{\circ} \mathrm{C}$. The removal of hafnium oxide film deposited in a reactor is expected to be effectively performed at moderately high temperatures.

\section{1. 序 論}

情報通信機器の主要部は, 極めて微細な電子回路により構 成されている。これらは, 沢山の種類の物質により形作られ た複雑な微細構造から成り立っている。このような電子回路 を品質良く形成するためには拡散, 薄膜形成, イオン注入, エッチング，めっき，など種々のプロセス技術が用いられて いる.これらのうち薄膜形成は, 極めて薄い層を広く均一に 形成するために用いられている.

薄膜形成の方法には原料蒸気を物理的手段により供給する 方法 (Physical Vapor Deposition, PVD) と原料化学物質を 化学工学的過程に基づいて供給する方法 (Chemical Vapor Deposition, CVD）がある. CVD 法は, 半導体薄膜（シリコ ン, 炭化珪素, 窒化ガリウムほか) などの形成に用いられて いる. 電気的絶縁膜については, 二酸化珪素に代わる材料と して酸化ハフニウム $\left(\mathrm{HfO}_{2}\right)$ を主成分とする極めて薄い膜 を形成する必要に迫られたため, CVD 法を発展させて原子 層を制御しながら形成する方法（原子層堆積法, Atomic layer Deposition, ALD) が開発されている.

CVD 法とALD 法は, どちらも化学反応を活用して薄膜 を形成する方法であり, 化学工学的視点から大きな違いはな い. そこで, CVD 法に扔いて生じる課題が ALD 法にも生 じ得るのであり, ALD 法に打ける課題を解決する方法が CVD 法の要素技術の中に見出されることは不思議ではない.

そこで, 本稿では, CVD 法とALD 法を簡単に比較した 後, 薄膜形成技術を工業的に用いる場合の現実的課題を整理 する．それらのうち反応環境を清浄に維持するためのクリー ニング技術について紹介し，併せてクリーニング技術を検討 する場合の視点を述べる. 次に, $\mathrm{HfO}_{2}$ 用 $\mathrm{ALD}$ リアクタの クリーニングに用い得る化学反応について検討し, その可能

* 平成 22 年 6 月 2 日 日本真空協会 2010 年 6 月研究例会で主要 部を講演

*1 横浜国立大学大学院工学研究院（干 $240-8501$ 神奈川県横浜市 保土ヶ谷区常盤台79-5)
性について調べた結果1,2)を紹介する.

\section{CVD 法と ALD 法}

CVD 法と ALD 法は, 共に気相を経由して原料を基板に 届け, 反応器内の化学反応を活用して薄膜を形成する方法で ある. CVD 法においては原子・分子層の形成を連続して進 行させ, ALD 法に拈いては原子・分子層を一層ずつ断続的 に形成させることが一般的特徵である.

CVD 法の代表例にシリコン $(\mathrm{Si})$ エピタキシャル成長 $\left.{ }^{3}\right)$ がある.（1)式は，Siエピタキシャル薄膜を形成するために 工業的に最も広く用いられている化学反応の総括式である.

$\mathrm{SiHCl}_{3}+\mathrm{H}_{2} \longrightarrow \mathrm{Si}+3 \mathrm{HCl}$

これは, トリクロロシラン $\left(\mathrm{SiHCl}_{3}\right)$ と水素 $\left(\mathrm{H}_{2}\right)$ から $\mathrm{Si}$ と塩化水素 $(\mathrm{HCl})$ を生成する化学反応である. その素反応 は(2)式と(3)式抢よび Fig. 1 に示す通り，2つに分けられ る.

$$
\begin{gathered}
\mathrm{SiHCl}_{3} \longrightarrow * \mathrm{SiCl}_{2}+\mathrm{HCl} \uparrow \\
{ }^{*} \mathrm{SiCl}_{2}+\mathrm{H}_{2} \longrightarrow * \mathrm{Si}+2 \mathrm{HCl} \uparrow \\
*: \text { 表面に化学吸着した状態 }
\end{gathered}
$$

最初に, $\mathrm{SiHCl}_{3}$ が $\mathrm{Si}$ 基板の表面に届いて化学吸着し, 中 間体として* $\mathrm{SiCl}_{2}$ を基板表面に形成する。 ${ }^{*} \mathrm{SiCl}_{2}$ により表面 が覆われた場合，その被覆層の表面は塩素（ $\mathrm{Cl} ）$ 原子により

\section{Sequentially non-stop,}

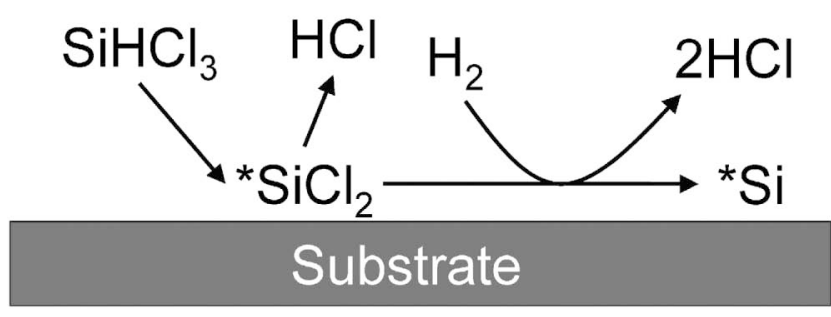

Fig. 1 Silicon epitaxial growth process. 
終端された状態となる.これは比較的安定であるために * $\mathrm{SiCl}_{2}$ の上に $\mathrm{SiHCl}_{3}$ は化学吸着できないと考えられてい る. そこで, * $\mathrm{SiCl}_{2}$ により表面が覆われると, それ以上に * $\mathrm{SiCl}_{2}$ が増えることなく飽和する. 次に, この* $\mathrm{SiCl}_{2}$ と $\mathrm{H}_{2}$ が化学反応し, 表面の $\mathrm{Cl}$ 原子が $\mathrm{HCl}$ となって取り除かれる ことにより*Si が形成される。この過程を繰り返すことによ り $\mathrm{Si}$ エピタキシャル成長が進行する. 薄膜形成の速度は, 化学反応速度論に基づき, ラングミュア型に記述3)される.

薄膜形成の様子を更に詳しく記述すると，（2)式と(3)式 は一つずつ順序を乱さずに交互に進み, Si 原子からなる層 を基板表面側から秩序を保って順序良く積み上げて行く．こ の機構であるため, 形成された薄膜の内部に欠陥などは少な く, 高品質の結晶薄膜が得られる.

しかしながら，その進行の様子は反応環境における原料分 子の輸送速度と表面化学反応の速度に支配され，表面におい ても場所毎に速度の大小がある.ガス流や基板回転などを工 夫して原料の輸送状態を最適化することにより, 大口径ウエ 八全体に亘って均一性の良い Si エピタキシャル薄膜が工業 的に形成されているものの，成長速度には大きな分布が潜ん でいることが珍しくない．即ち，CVD法において形成され る薄膜の形成速度と厚さは, 原子レベルで眺めれば原理的に 不揃いである.

次にALD 法による薄膜形成について簡潔に紹介する. ALD 法においては原料分子が表面に吸着し，その層を一層 形成した後に表面化学反応が自己停止する. 次に, 新たに別 種の原料を供給し，目的とする物質を形成すると同時に，停 止した化学反応を解除する. この過程で, 目的とする物質の 層が一層形成される，これを繰り返すことにより，薄膜を原 子レベルにおいて一層ずつ断続的に形成させることが特徴で ある・

$\mathrm{ALD}$ 法の一例として，塩化ハフニウム $\left(\mathrm{HfCl}_{4}\right)$ を用い た $\mathrm{HfO}_{2}$ 薄膜形成 ${ }^{4)}$ にいて紹介する. 総括化学反応の例は (4) 式の通りである. $\mathrm{HfCl}_{4}$ と水 $\left(\mathrm{H}_{2} \mathrm{O}\right)$ を原料とし，これ らから $\mathrm{HfO}_{2}$ と $\mathrm{HCl}$ を生成する。

$$
\mathrm{HfCl}_{4}+2 \mathrm{H}_{2} \mathrm{O} \longrightarrow \mathrm{HfO}_{2}+4 \mathrm{HCl}
$$

(4)を ALD 法の特徵的素反応に書き分けると (5)式，（6)式 および Fig. 2 に示す通りである.

$$
\begin{aligned}
& \mathrm{HfCl}_{4} \longrightarrow * * \mathrm{HfCl}_{4} \\
& * * \mathrm{HfCl}_{4}+2 \mathrm{H}_{2} \mathrm{O} \longrightarrow \mathrm{HfO}_{2}+4 \mathrm{HCl}
\end{aligned}
$$

ここで, “**”は, 表面に吸着した状態を示す。

ALD 法の特徵は，(5)式と（6)式の二つに書き分けられた 化学反応を分離して行うことにある. $\mathrm{HfCl}_{4}$ を基板に供給す ると, $\mathrm{HfCl}_{4}$ 分子が基板の表面に吸着し, 表面を覆い尽く す。ここで, 吸着した $\mathrm{HfCl}_{4}$ の層の上に更には重なって吸着 しないため, $\mathrm{HfCl}_{4}$ の吸着層は一分子層となり, 更に進行す ることなく自動的に停止する.

次に, $\mathrm{HfCl}_{4}$ の供給を停止し, リアクタ内を排気した後に $\mathrm{H}_{2} \mathrm{O}$ 分子を供給する. $\mathrm{H}_{2} \mathrm{O}$ 分子は表面に吸着されていた $\mathrm{HfCl}_{4}$ と反応し, $\mathrm{Cl}$ 原子を $\mathrm{HCl}$ の形に変えて取り除くと同 時に, $\mathrm{Hf}$ に $\mathrm{O}$ を 2 原子与えて $\mathrm{HfO}_{2}$ を形成する。これによ り 1 分子層の $\mathrm{HfO}_{2}$ 膜が形成される. 化学反応過程に従って 厳密に一分子の層が形成されるため, 必要な膜の厚さを得る

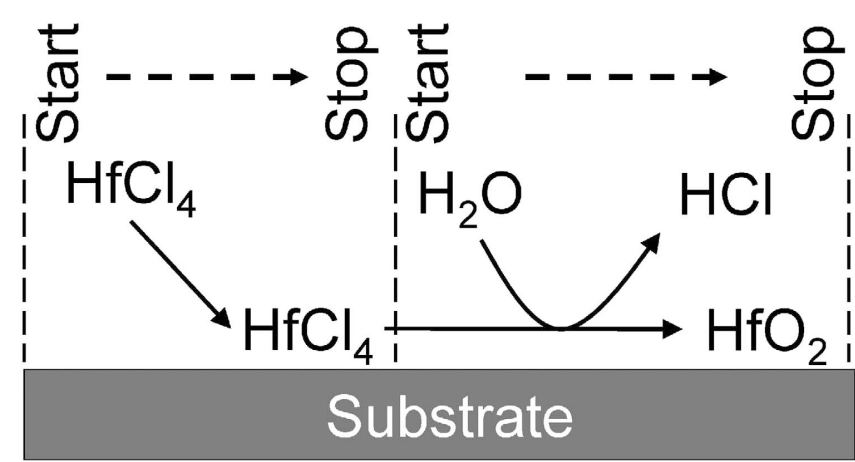

Fig. 2 Hafnium oxide film formation process by atomic layer deposition.

ためには，必要な回数だけ (5) 式と (6) 式を繰り返すことと なる.

$\mathrm{Si}$ エピタキシャル成長と $\mathrm{HfO}_{2}$ 原子層堆積は, どちらも原 料分子の表面吸着と反応の 2 段階から成っているが, 前者 では 2 つ素過程を連続して進行させ, 後者ではそれらを 断続・分離して行うことが相違点である.

\section{3. 工業生産における薄膜形成工程と課題}

種々の薄膜を工業的に生産する場合には，得られる薄膜の 厚さだけでなく，その品質を満足させなければならない，薄 膜の品質には, 不純物污染, 薄膜内部の結晶欠陥, 薄膜表面 の形態,などがある。

不純物，主に金属などによる污染を減らすためには，使用 するガスの高純度化, リアクタ内に置いている部品の高純度 化，ステンレス部材の表面保護，など5)が挙げられる.

薄膜表面の形態には, 膜厚の凹凸, 突起などがある. 基板 全体に及ぶ膜厚の凹凸については，ガス導入方法に起因する 場合6)がある. 実際に薄膜形成において生じる主な問題の一 つは, 突起の形で生じる表面欠陥である，基板表面に大小の 突起が形成される主な原因には, 異物の付着が多い。即ち, 付着した異物を取り込んで薄膜が形成されることにより, 種 々の形態の表面欠陥を生じること7) が問題である.

次に, 突起を形成する原因となる異物の発生原因について 簡潔に触れる，異物には，予め基板に付着していたもの，リ アクタ内において付着するものがある. 後者はリアクタの維 持・管理に関わることであるから，これを議論するために は，薄膜形成プロセス全体について説明しなければならない。

薄膜を生産するプロセスは, 一般に Fig. 3 のように構成 され，成膜に関する工程と，清浄化（クリーニング）する工 程から成る. 成膜工程においては，基板を挿入（ロード）し た後, キャリアガスを用いて必要なガス雾囲気に置換して温 度を調整し, 原料ガスを導入して膜を形成する. 所定の時間 だけ膜を形成した後には原料ガスの供給を停止し，キャリア ガス中で温度を下げた後に安全なガス雾囲気に置換し, 基板 を取り出す.

異物が付着する可能性を有する機会は, 原料を導入して膜 を形成する時だけではない，基板を仕込んだ後にゲートバル ブを開閉する時，キャリアガスを導入するためのバルブ開閉 時, 昇温により自然対流が発生する時, および自然対流が形 


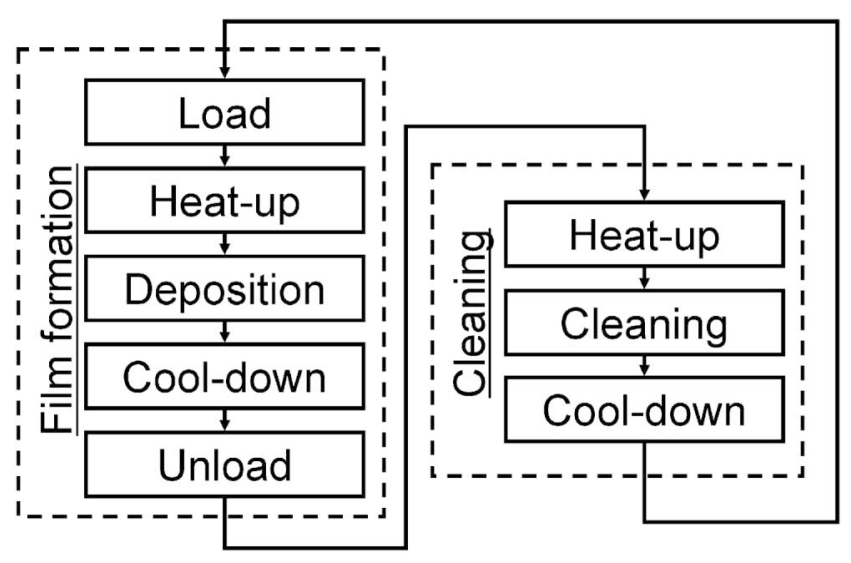

Fig. 3 Entire process for thin film deposition.

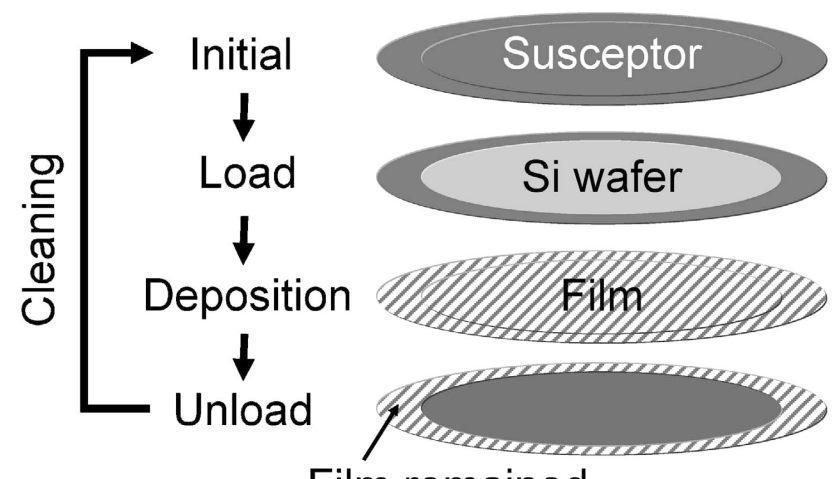

Film remained

Fig. 4 Film deposition on substrate and susceptor.

成されている間，原料ガスを導入するためにバルブが開閉す る時, など複数ある。これらは，何れもガスの輸送に関わる 変化が生じ, リアクタ内の圧力に何らかの変化が生じる時で ある.これらの時に, リアクタ内に存在していた微粒子, 或 いは，圧力変動により剥離して形成された微粒子が，その場 所を離れて気相に移り，ガスにより運ばれて基板の表面に到 着し，付着することにより異物付着が生じる.

これらの微粒子の発生源として最も大きな可能性を有する ものが，基板支持台（サセプタ）である．その様子を Fig. 4 を用いて説明する.

工程の最初において清浄なサセプタに基板を置き，そこに 成膜用のガスを導入すると, 基板の温度と原料ガスの濃度に より決定される化学反応速度に従って, 基板の表面に膜が形 成される.ここで, サセプタは基板に近い温度に維持されて いることが殆どであるため, 原料ガスが届けばサセプタ表面 にも基板上に匹敵する厚さだけ薄膜が形成されることが多い.

基板表面に形成される膜は, 基板の性質・結晶性に従って 秩序を保って形成された緻密な単結晶膜などであり, 高品質 である.こ扎比較して, サセプタ表面に扔いては自発的に 無数の核が発生して成長する過程を主とするため, 無秩序に 形成され，小さな結晶粒からなる膜であることが多い．更に は, サセプタの端においては充分な温度に加熱されていない 場合があることから，原料の分解が不充分となって反応中間 体が残留するなど，種々の可能性を包含する低品質膜とな
る.これは, 個別に発生した核から成長した粒子同士が付着 するように形成されるために, 膜が緻密である保証もなく, 機械的には脆い膜であると理解すべきである. サセプタだけ でなく, リアクタの内壁にも膜が堆積することがあり, その 膜についてもサセプタと同様或いはそれよりも無秩序に形成 された膜であると推定される.

成膜が終了して基板を取り出した後には, サセプタの中央 は成膜前の表面のまま保たれ，粒子付着のない状態が維持さ れているものの, その外周部には成膜時に堆積した膜がその まま残留する. サセプタ外周の堆積膜を残したままで成膜を 繰り返した場合, その回数分だけ堆積膜が厚くなる. その膜 の質は上記の通り脆いため, 何らかの衝撃が加わった場合に は容易に剥離し, 微粒子を発生する可能性が大きい。膜から 剥離して生じた破片・粒子が基板の表面に付着すると，それ が取り込まれるように膜が形成されるため, 薄膜の表面には 突起が形成される.ここに打いて衝撃には, 上述のようにガ スバルブの通常の操作において発生する圧力変動などが該当 する.

このような突起を有する薄膜であっては, 微細な構造であ る電子デバイスの作製に用いることはできない，そこで，サ セプタに堆積した膜を適宜除去し，Fig. 4 に抢ける初期の状 態に戻さなければならない，その工程が，Fig. 3 に扔けるク リーニング工程である.クリーニング工程においては, 基板 を取り出した後に温度を上げ, 腐食性のガス $(\mathrm{HCl}$ ガスな ぞ）を導入してサセプタ表面に残留していた膜を除去するこ とが一般的である.

\section{4. リアクタクリーニング : 事例と視点}

ここでは, リアクタクリーニング方法について, $\mathrm{Si}$ エピ タキシャルリアクタの事例を紹介すると共に, クリーニング 方法を開発する場合の視点を紹介する.

$\mathrm{Si}$ エピタキシャルリアクタに扔いては, サセプタに付着 した Si 膜を除去するために, $1200^{\circ} \mathrm{C}$ 付近において $\mathrm{HCl}$ ガス を用いることが一般的である.その化学反応は次式の通りで ある.

$$
\mathrm{Si}+3 \mathrm{HCl} \longrightarrow \mathrm{SiHCl}_{3} \uparrow+\mathrm{H}_{2} \uparrow
$$

(7) 式は (1) 式に示した Si エピタキシャル成長の逆反応であ り, $\mathrm{HCl}$ ガスが $\mathrm{Si}$ と反応して $\mathrm{SiHCl}_{3}$ ガスと $\mathrm{H}_{2}$ ガスを発生 する化学反応である。多結晶 Si 膜を除去する速度に関する 報告例は見当たらないものの, $\mathrm{Si}$ 単結晶を $\mathrm{HCl}$ によりエッ チングした速度について報告8 されている。その報告によれ ばエッチング速度は $\mathrm{HCl}$ ガス濃度に比例し, 毎分 $10 \mu \mathrm{m}$ 以 上である.

(7)式に抢ける生成物の沸点について述べると, 生成物で ある $\mathrm{SiHCl}_{3}$ の沸点は室温近傍 $\left(33^{\circ} \mathrm{C}\right)$ であることから, 高 温に拉いて容易に気化する. そこで, 排ガス管の温度を適正 化することにより, $\mathrm{SiHCl}_{3}$ を気体状のままでリアクタ・排 ガス管の下流に運び去ることが可能である.

$\mathrm{Si}$ を除去する方法としては, この他に三フッ化塩素 $\left(\mathrm{ClF}_{3}\right)$ ガスを用いる方法9)が知られている。 その反応式は 次の通りである.

$$
3 \mathrm{Si}+4 \mathrm{ClF}_{3} \longrightarrow 3 \mathrm{SiF}_{4} \uparrow+2 \mathrm{Cl}_{2} \uparrow
$$


$\mathrm{ClF}_{3}$ ガスと $\mathrm{Si}$ は室温においても活発に反応するため, サセ プタやリアクタを加熱する必要がない，従って，リアクタ内 に掞いて $\mathrm{HCl}$ とは反応できない程度にしか加熱できない領 域に付着していた Si 膜を除去することも可能である.

やはりここで反応生成物について述べると, $\mathrm{SiF}_{4}$ の沸点 は $-95.7^{\circ} \mathrm{C}$ であり, $\mathrm{Cl}_{2}$ ガスの沸点も極めて低い. 従って, これらの反応生成物は, 何れも容易にリアクタの外に運び出 される。

これらのクリーニング技術において共通する要点は, 生成 物の沸点が低いことである。この視点を用いて, 次に, $\mathrm{HfO}_{2}$ について検討する.

$\mathrm{HfO}_{2}$ 膜が基板以外の場所に形成された場合，それを除去 するためには何らかの低沸点化合物に変えて気化させなけれ ばならない，そこで，主要な Hf 化合物の沸点・昇華点につ いて知られている值 ${ }^{10)}$ を $\mathrm{Si}$ の化合物と共に Table 1 に列挙 する.

用い易い腐食性ガスがハロゲン化水素, ハロゲンであるこ とを考えると, 八ロゲン化物を中心に生成物を検討すること となる. Table 1 によれば, Hf のフッ化物の昇華点が 1000 ${ }^{\circ} \mathrm{C}$ 付近であり, 塩化物の沸点も $300^{\circ} \mathrm{C}$ 付近である. その他, 臭化物， ヨウ化物の昇華点についても $300^{\circ} \mathrm{C}$ 以上である.こ のように何れの沸点・昇華点も Si 化合物に比して高いこと が分かる。

ハロゲン化物以外では，有機金属錯体を形成する方法が報

Table 1 Physical properties of silicon and hafnium compounds (Boiling point and sublimation point)

\begin{tabular}{c|c|c}
\hline \hline & Silicon & Hafnium \\
\hline Element & $2335^{\circ} \mathrm{C}$ & $>3200^{\circ} \mathrm{C}$ \\
\hline Oxide & $2230^{\circ} \mathrm{C}$ & $5400^{\circ} \mathrm{C}$ \\
\hline Fluoride & $-96^{\circ} \mathrm{C}(\mathrm{Sub})$ & $>968^{\circ} \mathrm{C}(\mathrm{Sub})$ \\
\hline Chloride & $33^{\circ} \mathrm{C}$ & $\begin{array}{c}316^{\circ} \mathrm{C}(\mathrm{Sub}) \\
\mathrm{VP}: 130 \mathrm{~Pa}\left(170^{\circ} \mathrm{C}\right)\end{array}$ \\
\hline Bromide & $153^{\circ} \mathrm{C}$ & $322^{\circ} \mathrm{C}(\mathrm{Sub})$ \\
\hline Iodide & $288^{\circ} \mathrm{C}$ & $400^{\circ} \mathrm{C}(\mathrm{Sub})$ \\
\hline Complex & - & $\begin{array}{r}\mathrm{Hf}(\mathrm{HFAc})_{4} \\
\mathrm{VP}: 130 \mathrm{~Pa}\left(70^{\circ} \mathrm{C}\right)\end{array}$ \\
\hline
\end{tabular}

Sub : Sublimation

VP : vapor pressure

HFAc: 1, 1, 1, 5, 5, 5-hexafluoro-2, 4-pentanedione

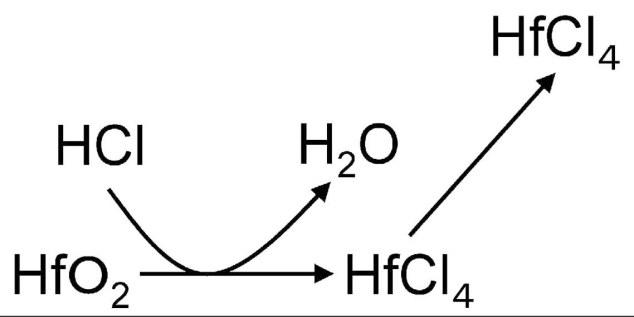

\section{Substrate}

Fig. 5 Process for producing hafnium chloride from hafnium oxide.
告11)されている.これは, 1,1,1,5,5,5-hexafluoro-2,4-pentanedione (HFAc) と反応させて $\mathrm{Hf}(\mathrm{HFAc})_{4}$ を形成する方

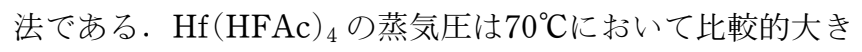
い值（130 Pa）を示すため, 有用なクリーニング法として 期待されている.

本稿では, $\mathrm{Hf}$ 塩化物の昇華点が $\mathrm{Hf}$ 化合物の中では比較 的低いことから, $\mathrm{HfO}_{2}$ から $\mathrm{HfCl}_{4}$ を形成する方法について 検討する. 塩化物を生成するための腐食性ガスとして, $\mathrm{HCl}$ ガスを用いることとする. $\mathrm{HCl}$ ガスは, 入手し易く, 半導 体プロセスにおいて使用実績が豊富であること, 配管内で液 化しにくいことなどの利点を有しているため, 工業生産プロ セスに使い易いガスである.

$\mathrm{HfO}_{2}$ を $\mathrm{HfCl}_{4}$ に変える化学反応は, Fig. 5 に示す通りで ある。これは上記の (4) 式の逆反応, 即ち,

$$
\mathrm{HfO}_{2}+4 \mathrm{HCl} \longrightarrow \mathrm{HfCl}_{4} \uparrow+2 \mathrm{H}_{2} \mathrm{O} \uparrow
$$

である. 次節以降では, (9) 式の化学反応が生じる様子を $\mathrm{HfO}_{2}$ の粉末と薄膜の場合について実験により調べた結果を 紹介する。

\section{5. $\mathrm{HfO}_{2}$ の化学反応}

(9)式の化学反応が生じることを調べるために用いた実験 装置を Fig. 6 に示す. $\mathrm{HfO}_{2}$ 粉末試料を石英ガラス製の小皿 に入れ，それを多結晶 $3 \mathrm{C}-\mathrm{SiC}$ 板の上に置く．これを石英ガ ラス製リアクタの中に挿入した. その外側から赤外線ランプ (ハロゲンランプ）で加熱して昇温させ, $\mathrm{HCl}$ ガスに暴露し た。

前述のように, 一般に基板以外の箇所に薄膜が堆積する場 合には，必ずしも制御されているとは限らない状態で形成さ れることが多く, 細かな粒子の集合体になることが多い。そ こで，ここでは $\mathrm{HfO}_{2}$ 粉末を試料して用いた. $\mathrm{HfO}_{2}$ 粉末の 量は, 約 $0.02 \mathrm{~g}$ であった.

エッチングの工程を Fig. 7 に示す. 試料を Fig. 6 に示す ようにリアクタ内に挿入した後, $\mathrm{H}_{2}$ 䨌囲気中で昇温した. 試料の温度は $300^{\circ} \mathrm{C} \sim 1000^{\circ} \mathrm{C}$ である. 所定の温度に到達した 後, $\mathrm{HCl}$ ガス $(100 \%)$ の雾囲気に切り替え, $60 \sim 180$ 分保 持した. $\mathrm{HCl}$ ガスの流量は $100 \sim 300 \mathrm{sccm}$ であった。 その 後, $\mathrm{H}_{2}$ 䨌囲気に戻し, 降温した. 全体を通して圧力は 1 気圧 であった. エッチング前後における $\mathrm{HfO}_{2}$ 粉末の外観の変化 と重量差を用いて，化学反応の進行の様子を考察した。 $800^{\circ} \mathrm{C}$ および $1000^{\circ} \mathrm{C}$ 抢いて $\mathrm{HCl}$ ガスによりエッチングし

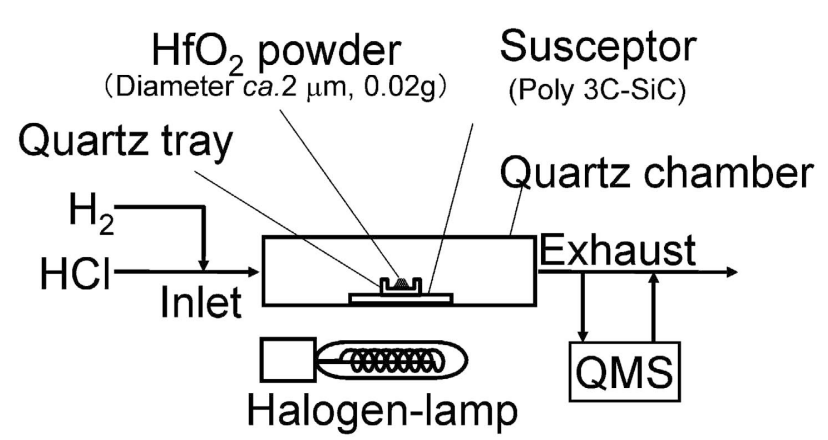

Fig. 6 Reactor for etching of hafnium oxide (powder). 


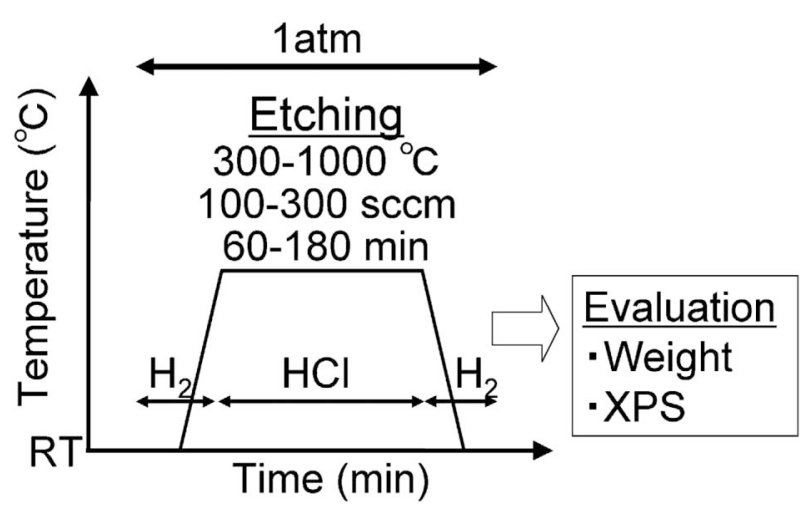

Fig. 7 Process for etching of hafnium oxide using hydrogen chloride gas.

(a)

Before etching

After etching

(b)
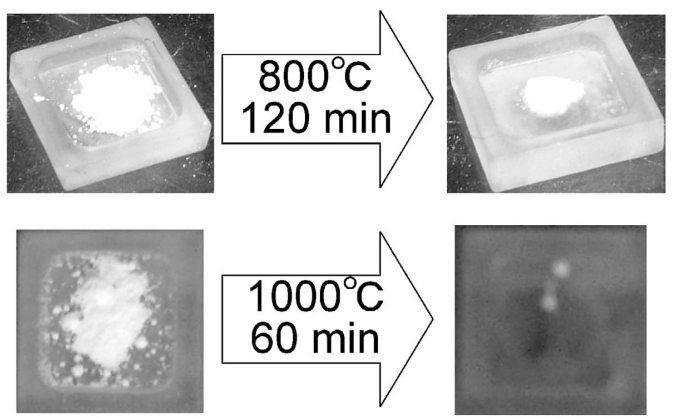

$\mathrm{HfO}_{2}:$ ca. $0.02 \mathrm{~g}$,

$\mathrm{HCl}$ gas: $100 \%, 100 \mathrm{sccm}, 1 \mathrm{~atm}$

Fig. 8 Change in appearance of hafnium oxide powder, etched at $800^{\circ} \mathrm{C}$ (a) and $1000^{\circ} \mathrm{C}(\mathrm{b})$.

た際の $\mathrm{HfO}_{2}$ 粉末の外観の変化の様子を Fig. 8 に示す. 左 側がエッチング前, 右側がエッチング後の様子である.

$800^{\circ} \mathrm{C}$ において $\mathrm{HCl}$ ガスに 120 分間暴露した際の变化の様 子を Fig. 8(a) に示す. $\mathrm{HCl}$ ガスに暴露する前には血の中央 に $\mathrm{HfO}_{2}$ 粉末がまとまって置かれ, その周囲に粉末の粒子が 散乱している.これを $800^{\circ} \mathrm{C} に$ 扔いて $\mathrm{HCl}$ ガスに暴露するこ とにより, 粉末全体の量が明らかに減少していることが分か る. その様子を詳しく観察すると, 石英ガラス容器の中央に 置かれていた $\mathrm{HfO}_{2}$ 粉末の山が，その中心の位置を移動する ことなく全体に低くなっていること, 粉末の周囲に散在して いた粉末が消失していること, 粉末が一定方向に尾を引くよ うな分布になっていないことが認められる. 以上から， $\mathrm{HfO}_{2}$ 粉末の減少は, リアクタ内のガス流により飛散したの ではなく, $\mathrm{HCl} に よ り$ 生じた化学反応により, 粉末の山の 外側から減少して行ったことによるものと判断される.

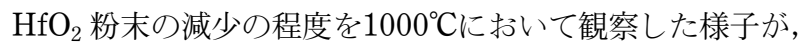

Fig. 8(b)である. $\mathrm{HCl}$ ガスに60分間暴露して様子を観察し たところ, 粉末が僅かに残留していたものの試料の殆どが消 失していたことが認められた。

反応の様子を数值化するため, $300 \sim 1000^{\circ} \mathrm{C}$ 温度範囲に おいて $\mathrm{HfO}_{2}$ 粉末の減少量を調べ，その結果から (10)式に従 って反応率を求めた。

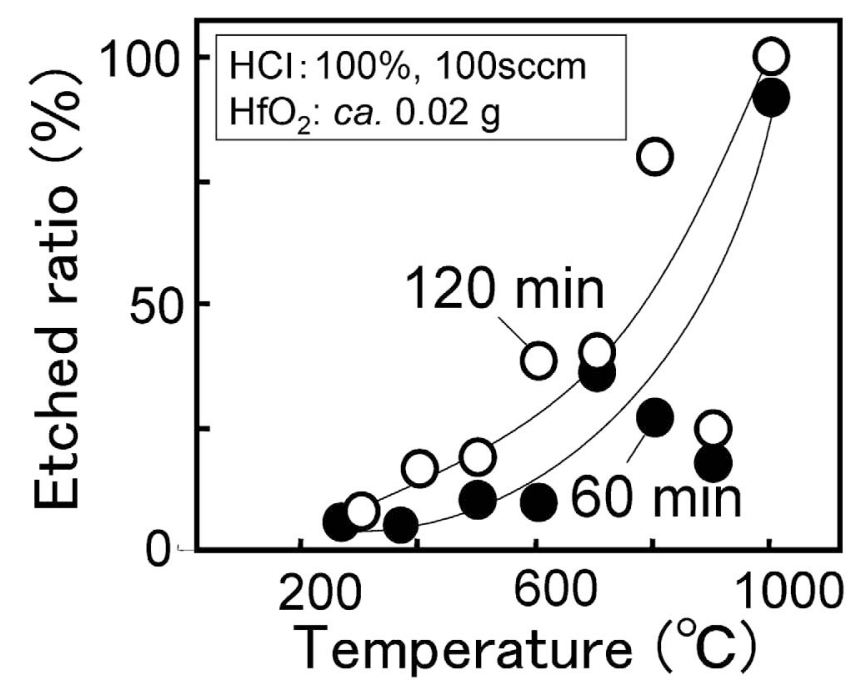

Fig. 9 Etched ratio of hafnium oxide powder.

$$
\text { 反応率 }=\left(W_{0}-W_{\mathrm{E}}\right) / W_{0} \times 100
$$

ここで, $W_{0}, W_{\mathrm{E}}$ はそれぞれエッチング前とエッチング後の 粉末の重量である。（10)式により得られた反応率を Fig. 9 に示す. $300^{\circ} \mathrm{C}$ 以下では反応率は極めて小さく, 無視し得る 程度である. 温度を上げるに伴って反応率は増大し, 反応率 は $700^{\circ} \mathrm{C}$ 付近に扮いて $40 \%$ 近い值となる. $900^{\circ} \mathrm{C}$ 付近に反応

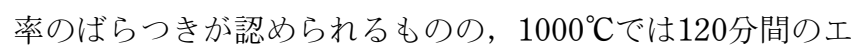
ッチングの後には試料が全て消失していた. 以上の結果を基 に, $\mathrm{HCl}$ ガスを用いて $\mathrm{HfO}_{2}$ を除去することは可能であるこ とが結論された。

次に, $\mathrm{HfO}_{2}$ 粉末が減少した原因が化学反応にあることを 示すため, $\mathrm{HfO}_{2}$ と $\mathrm{HCl}$ の化学反応に繋がる現象を調べた.

最初に, Fig. 6 に示すようにリアクタから排出されるガスの 一部を採取して四重極質量分析器により分析した。しかしな がら, 排出ガス中に $\mathrm{HCl}$ ガスが検出されるものの, $\mathrm{Hf}$ に関 連する化合物は全く検出されなかった．Fig. 9 に示されて いると抢り, エッチングにより粉末が減少し始める温度が $300^{\circ} \mathrm{C}$ 付近であること, $\mathrm{HfCl}_{4}$ の昇華点が $300^{\circ} \mathrm{C}$ 以上であるこ と, 排出ガスは反応域を出て四重極質量分析器に入るまでの 経路において充分に冷やされることを総合すると, エッチン グによって生成した物質が $\mathrm{HfCl}_{4}$ であり，それがリアクタの 下流側の低温域において全て堆積していたために, 排出ガス 中に Hf 化合物が含まれなかったことが理解される.

次に，リアクタ壁に付着していた堆積物の様子を考察し た. 反応生成物が $\mathrm{HfCl}_{4}$ であった場合には, リアクタ下流側 のうち $300^{\circ} \mathrm{C}$ 付近に冷やされている領域を中心に $\mathrm{HfCl}_{4}$ の粒 子・膜が付着していることが予想される. そこで, リアクタ 内に抢ける化学反応により生起する現象を Fig. 10(a)に示 す.

リアクタ内の皿の底に置かれていた $\mathrm{HfO}_{2}$ 粉末は $\mathrm{HCl}$ ガ スと反応して $\mathrm{HfCl}_{4}$ となり, 気化して下流側に押し流され る.リアクタの下流側は反応域よりも低温であるため, $\mathrm{HfCl}_{4}$ は昇華点以下の温度になっている領域において堆積す ることが予想される．これを繰り返すことにより比較的厚い 膜として観察されるはずである，ここにおいて，エッチング 


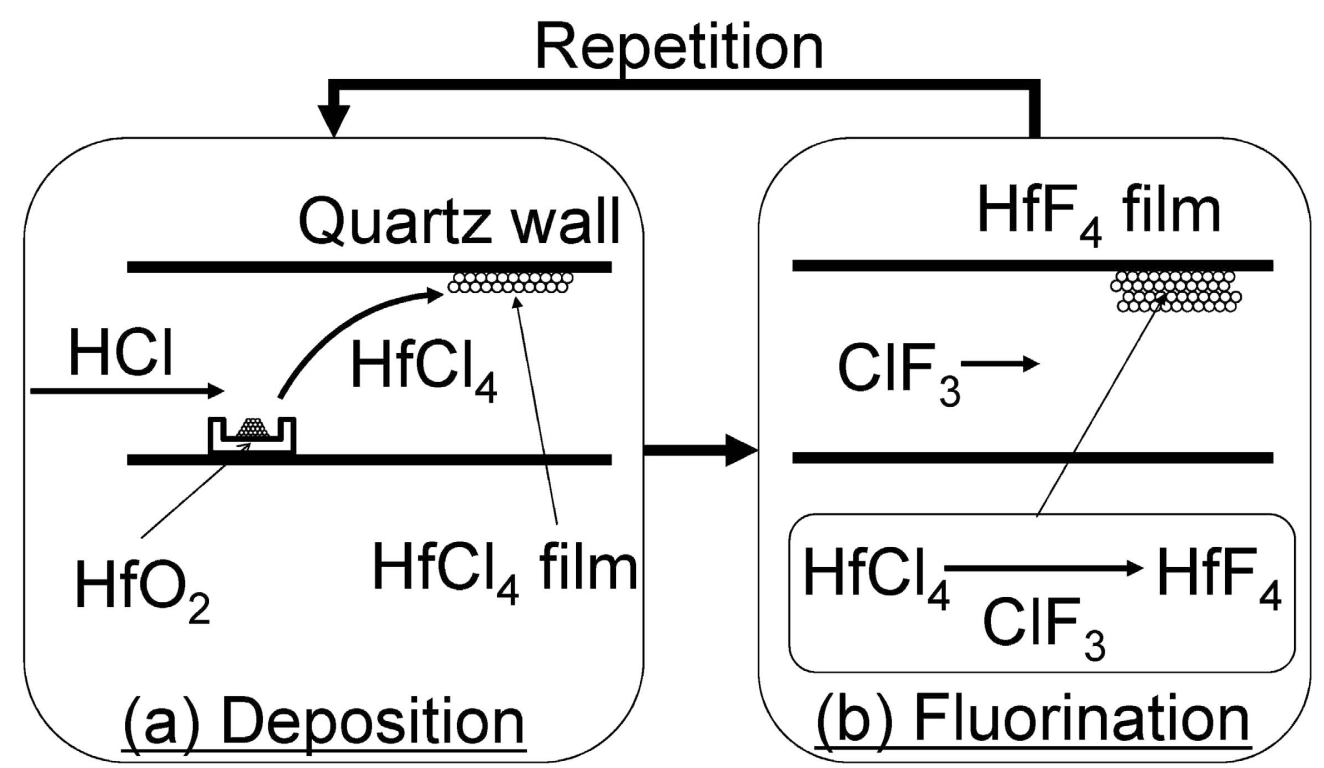

Fig. 10 Chemical reactions of hafnium oxide occurred in a cold wall reactor.

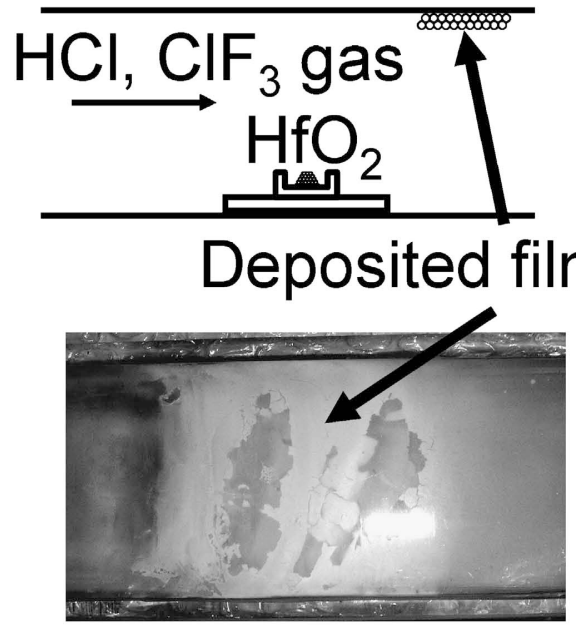

(a) After etching

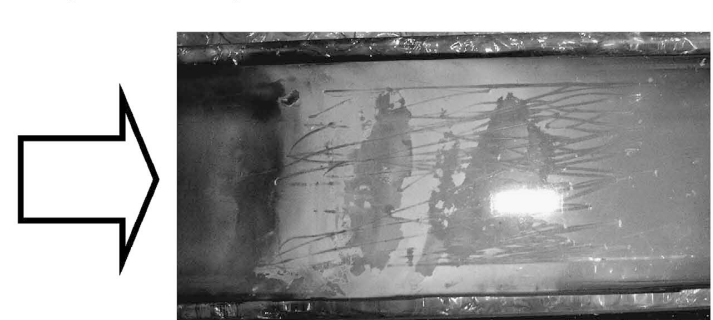

(b) After scratching and peeling off

Fig. 11 Film formed on inner wall of the reactor. (a) after etching by $\mathrm{HCl}$ and fluorination by $\mathrm{ClF}_{3}$; (b) after scratching and peeling off.

1 回当たりに形成される膜の厚さは極めて小さいことが予想 されると共に, 種々の温度を用いてエッチングした場合に は，その温度が高ければ堆積した膜が再び昇華する可能性が あった。そこで，確実に反応生成物を捕集するために， $\mathrm{HfCl}_{4}$ を昇華点が高い化合物に変えておくこととした．堆積 膜を $\mathrm{HfF}_{4}$ （昇華点約 $1000^{\circ} \mathrm{C}$ ) に変えるため, $\mathrm{HCl}$ による工 ッチングを行った後に, リアクタ内に $\mathrm{ClF}_{3}$ ガスを流入させ た. その様子が Fig. 10 (b)である. $\mathrm{ClF}_{3}$ は強いフッ素化 剂4)であることから, リアクタに堆積していた $\mathrm{HfCl}_{4}$ と低温 において反応して $\mathrm{HfF}_{4}$ を生じることが期待された.

エッチングとフッ素化を Fig. 10 に示すように繰り返し， その後にリアクタ下流側を観察した様子が Fig. 11 (a)であ る.この写真は $\mathrm{HfO}_{2}$ 粉末が置かれていた反応域より下流側 であって, 赤外線加熱炉から外に出ているため, 室内の空気
により冷却されている箇所である.リアクタの上側の内壁に 白色の粉末からなる膜が形成され，その一部は剥がれている ことが認められた。そこで，その膜を Fig. 11(b)に示すよ うに，石英ガラス棒により削り落として採取した。

採取した粉末をXPSにより分析した結果を Fig. 12 に示 す. $500 \mathrm{eV}$ 以下の領域に Hf 原子に起因するピークが複数 観察されると共に, $700 \mathrm{eV}$ 付近と $800 \mathrm{eV}$ を越えた領域に $\mathrm{F}$ 原子に起因するピークが検出された．これに比して， $\mathrm{Cl}$ に 起因するピークは検出されなかった.

以上から, $\mathrm{HfO}_{2}$ 粉末は $\mathrm{HCl}$ の化学反応により $\mathrm{HfCl}_{4}$ とな り, 気化して下流側に運ばれて低温領域で堆積したこと, そ の後に $\mathrm{ClF}_{3}$ ガスにより $\mathrm{HfF}_{4}$ に変化したこと, 即ち, Fig. 10 に示すプロセスが進行したことが検証された. 


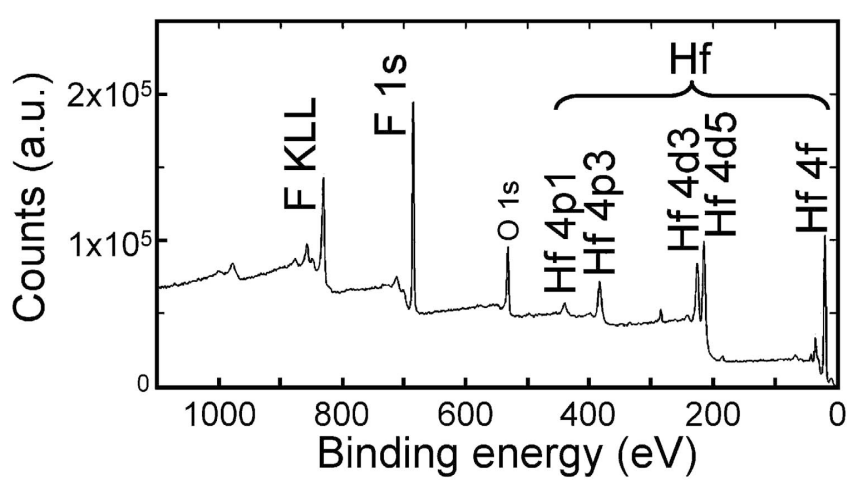

Fig. 12 X-ray photo electron spectra of film formed at the downstream region of reactor.

\section{6. $\mathrm{HfO}_{2}$ 薄膜の除去}

前節においては, 粉末状・多孔質の $\mathrm{HfO}_{2}$ をクリーニング する場合を想定し, 粉末試料を用いて $\mathrm{HCl}$ との化学反応を 調べた結果を紹介した. しかしながら, サセプタのうち基板 に隣接する領域においては基板に極めて近い条件に従って堆 積することとなり，その場合には堆積物が粉末状・多孔質の ものだけでなく, 比較的緻密な膜になることが予想される. そこで, $\mathrm{HfO}_{2}$ 薄膜についても $\mathrm{HCl}$ ガスを用いてエッチング を行い，エッチング速度を測定した。用いた装置はFig. 6 に同じであるが, 試料として多結晶 $3 \mathrm{C}-\mathrm{SiC}$ 基板の表面に有 機金属 CVD (MOCVD) 法により厚さ約 $100 \mathrm{~nm}$ に堆積され た $\mathrm{HfO}_{2}$ 膜を用いた. 試料の大きさは $3 \mathrm{~cm} \times 4 \mathrm{~cm}$ である. エッチング工程および条件はFig. 7 に同一とした。尚, $1000^{\circ} \mathrm{C}$ 付近に扔いて $100 \%$ の $\mathrm{HCl}$ ガスにより $\mathrm{SiC}$ 基板がエ ッチングされないことを予め確認した.

$800^{\circ} \mathrm{C}$ に拉いて 60 分間エッチングした後の表面を目視で観 察したところ, $\mathrm{HfO}_{2}$ 薄膜の色が消失して $3 \mathrm{C}-\mathrm{SiC}$ 結晶の色 が現れていたことから, 薄膜の殆どが除去されたものと推定 された. そこで, その様子を把握するため, 試料表面の化学 結合状態をXPSにより観察した. その結果を Fig. 13 に示 す.

Fig. 13 に示す通り, 試料の表面には Hf 原子と $\mathrm{O}$ 原子に 起因するピークが複数観察されていることから, $\mathrm{HfO}_{2}$ 膜が 残留していることが分かる. それと同時に， $\mathrm{SiC}$ 基板に起因 するものと推定される Si とCのピークが観察されている.

これらから, $\mathrm{HfO}_{2}$ 膜が残留しているものの, その量は僅か であることが分かった。そこで， $\mathrm{HCl}$ ガスに暴露する時間 を延長する, 或いは, 温度を上げることにより完全に除去で きるものと推定された.

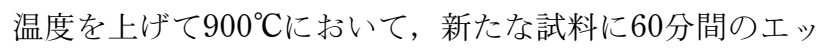
チングを行い，その試料の表面をXPSにより測定した。そ の結果を Fig. 14 に示す。この図に拈いてHfに起因する ピークは観察されなかったこと， $\mathrm{SiC}$ 基板に起因する $\mathrm{Si}$ と $\mathrm{C}$ が主に観察されていることから， $\mathrm{HfO}_{2}$ 膜は完全に除去さ れたものと考えられる.

尚, Fig. 14 には O 原子が僅かに観察されているが, 試料 をリアクタから取り出して後, XPS 測定を行うまでに長い 時間が経過していたことから, 空気中の有機物が付着し, そ

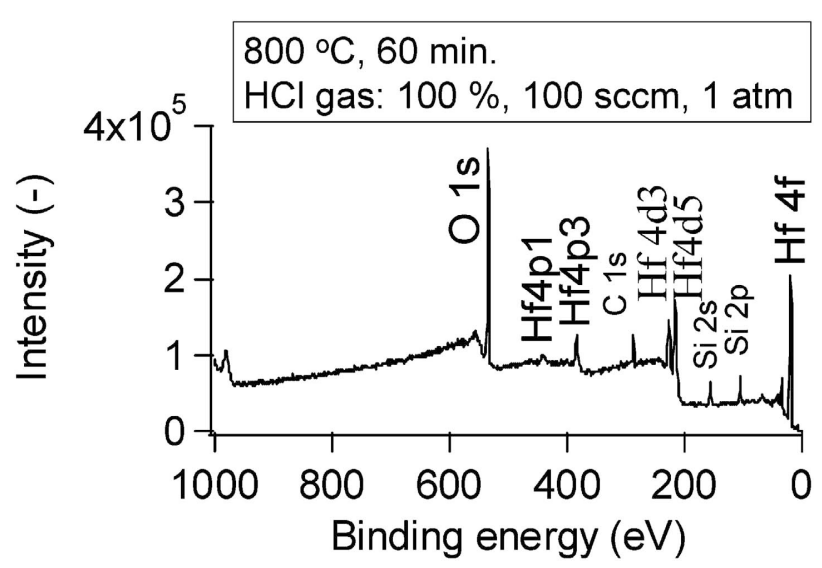

Fig. 13 X-ray photoelectron spectra of hafnium oxide film after exposed to $\mathrm{HCl}$ gas at $800^{\circ} \mathrm{C}$ for $60 \mathrm{~min}$.

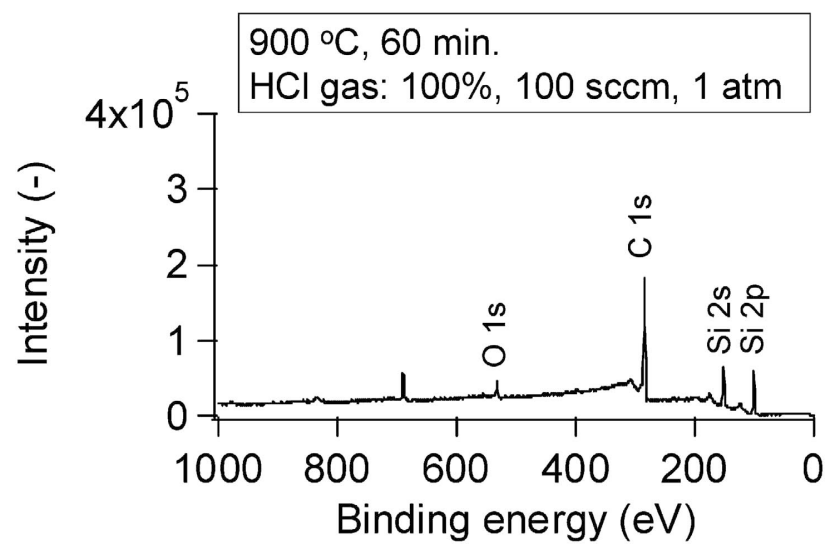

Fig. 14 X-ray photoelectron spectra of hafnium oxide film after exposed to $\mathrm{HCl}$ gas at $900^{\circ} \mathrm{C}$ for $60 \mathrm{~min}$.

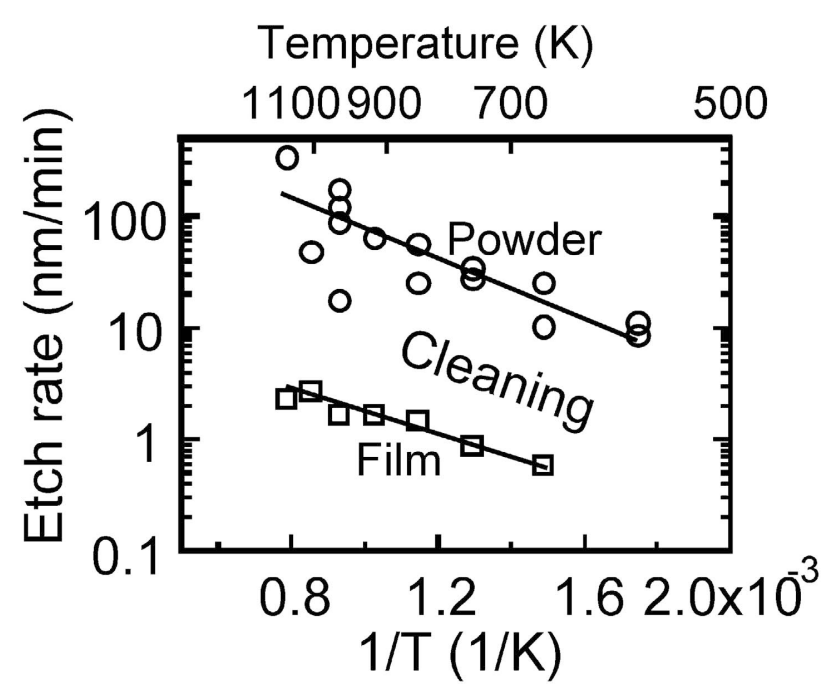

Fig. 15 Etching rate of hafnium oxide by hydrogen chloride gas.

の中の $\mathrm{O}$ 原子が検出されたものと推定される.

種々の温度に拈ける $\mathrm{HfO}_{2}$ 膜のエッチング速度を整理した 図が Fig. 15 である.この図には薄膜のエッチング速度に加 えて, 粉末のエッチング量を膜厚に換算して求めたエッチン グ速度を併せて示している。粉末のエッチング速度は, 
$\mathrm{HfO}_{2}$ を収めた小皿の面積を見掛けの反応面積として概算し た。

薄膜のエッチング速度は温度の上昇と共に大きくなり， $800^{\circ} \mathrm{C}$ では $2 \sim 3 \mathrm{~nm} /$ 分程度となる。これに対して，粉末の エッチング速度は薄膜の約 10 倍の大きさになるものと考え られる，これは，実効的な反応面積が大きいことが主な理由 であると推定される。

実際にリアクタ内に堆積した膜をクリーニングする際には, Fig. 15 における薄膜と粉末の中間のエッチング速度になる ものと推定される. 従って, $800^{\circ} \mathrm{C}$ 付近に沶いては, $2 \sim 3$ $\mathrm{nm} /$ 分以上であって最大では数 $10 \mathrm{~nm} /$ 分になり得ることが 推定される。

尚，エッチング速度が遅いために最後に残った膜が除去さ れることをもってリアクタクリーニングの完了を判断するこ ととなるため, 最小のエッチング速度についても考慮してお くことが必要である。

\section{7. まとめ}

$\mathrm{CVD}$ による $\mathrm{Si}$ エピタキシャル成長と $\mathrm{ALD}$ による $\mathrm{HfO}_{2}$ 膜形成を比較し，リアクタのクリーニング方法設計に関する 視点を紹介した. $\mathrm{HfO}_{2}$ 堆積膜を $\mathrm{HCl}$ により除去することを 想定して実験により調べたところ，300ㄷ上において化学 反応を生じ, $\mathrm{HfCl}_{4}$ を生成することが結論された. $\mathrm{HfO}_{2}$ の エッチング速度は, $800^{\circ} \mathrm{C}$ 付近においては, $2 \sim 3 \mathrm{~nm} /$ 分以上 であり，粉末状の場合には最大では数 $10 \mathrm{~nm} /$ 分になるもの と推定される.

\section{謝辞}

$\mathrm{HfO}_{2}$ のエッチングに関する研究は, (怢)日立国際電気の堀 井貞義氏, 国井泰夫氏, 抢よび, 横浜国立大学工学部の山地 正彦氏, 小堀嘉嗣氏との共同研究によるものであることを記 し，謝意を表します。

\section{〔文献〕}

1) H. Habuka, M. Yamaji, Y. Kobori, S. Horii and Y. Kunii: Jpn. J. Appl. Phys., 48 (2009) 125503.

2) H. Habuka, Y. Kobori, M. Yamaji, S. Horii and Y. Kunii: ECS Transactions, 19 (2009) 289.

3) H. Habuka, T. Nagoya, M. Mayusumi, M. Katayama, M. Shimada and K. Okuyama: J. Cryst. Growth, 169 (1996) 61.

4) J. Niinistö, M. Putkonen, L. Niinistö, K. Arstila, T. Sajavaara, J. Lu, K. Kukli, M. Ritala and M. Leskelä: J. Electrochem. Soc., 153 (2006) F39.

5) Ultra Clean Society: Shirikon No Kagaku, Realize Inc., Tokyo (1996).

6) H. Habuka, S. Fukaya, A. Sawada, T. Takeuchi and M. Aihara: J. Cryst. Growth, 266 (2004) 327.

7) M. Iwabuchi, K. Mizushima, M. Mizuno and K. Kitagawara: J. Electrochem. Soc., 147 (2000) 1199.

8) H. Habuka, T. Suzuki, S. Yamamoto, A. Nakamura, T. Takeuchi and M. Aihara: Thin Solid Films., 489 (2005) 104.

9) H. Habuka, H. Koda, D. Saito, T. Suzuki, A. Nakamura, T. Takeuchi and M. Aihara: J. Electrochem. Soc., 150(8), G461 (2003).

10) Nihon Kagaku Kai: Kagaku Binran, Maruzen Inc., Tokyo (2004).

11) T. Umezaki and I. Mouri: Ext. Abs. 2009 Fall Meeting of Japan Soc. Appl. Phys. 8p-TA-3 (2009). 